\title{
Nordiques
}

35 | 2018

Tove Jansson : Par delà les genres. Pratiques

linguistiques dans le Norden du XXIe siècle : Quels

enjeux sociaux?

\section{The Dancing Moominvalley: A Choreographic View on Tove Jansson's Illustrations and Texts}

Sirke Happonen

\section{OpenEdition}

Journals

\section{Electronic version}

URL: https://journals.openedition.org/nordiques/836

ISSN: 2777-8479

Publisher:

Association Norden, Bibliothèque de Caen la mer

\section{Printed version}

Date of publication: 1 May 2018

Number of pages: $55-73$

ISBN: 979-1-0959140-1-3

ISSN: 1761-7677

\section{Electronic reference}

Sirke Happonen, "The Dancing Moominvalley: A Choreographic View on Tove Jansson's Illustrations and Texts", Nordiques [Online], 35 | 2018, Online since 02 February 2021, connection on 06 October 2021. URL: http://journals.openedition.org/nordiques/836 


\title{
The Dancing Moominvalley: A Choreographic View on Tove Jansson's Illustrations and Texts
}

\author{
Sirke Happonen*
}

\section{RÉSUMÉ}

Cet article vise à mettre l'accent sur un aspect de la littérature de Tove Jansson, qui est lié à la danse et au mouvement. Il s'intéresse à son travail en tant que constructions chorégraphiques, aux images et textes qui renvoient à la danse. Cette dernière était une forme d'expression personnelle importante chez Tove Jansson, que l'on peut retracer dans son xuvre. Dans les livres sur les Moumines, l'acte de danser exprime différents sentiments et phases de la narration - joie de vivre, envie de s'échapper, rébellion et libération. Cependant, Jansson utilise aussi ces formes d'expression chorégraphiques lorsqu'elle décrit et illustre des événements qui sont associés à la danse, à l'instar de certains mouvements de la nature, de positions et postures humaines qui semblent particulièrement expressifs et esthétiques. De nombreux personnages dans l'auvre de Jansson ont un langage qui renvoie au mouvement qui leur est propre. Lorsqu'elle retranscrit ces impressions, Jansson emprunte aux conventions de la danse de salon, du ballet et de la danse moderne. A travers ces registres de la danse ou apparentés, elle met en scène des nuances exceptionnelles dans sa narration et son art et parvient ainsi à exprimer son sens de l'humour très personnel.

\section{ABSTRACT}

This article aims at highlighting Tove Jansson's literature from a specific viewpoint, related to dance and moving. It looks at her work as choreographic constructions, dancelike impressions created by both images and text. Dance was a close and important form of self-expression for Tove Jansson, and her interest in dance and movement can be seen by looking at her work, too. In Moomin books dancing expresses many feelings and phases in the stories - joy of life, escapism, rebellion and liberation. Jansson however uses choreographic expressions also when describing and illustrating events that are not actually dance but associate to dance, such as movements of nature and the characters' positions and postures that seem pronouncedly expressive and aesthetic. Many characters in Jansson's books have an individual movement language. When shaping these impressions Jansson draws ideas from certain dance conventions such as social dancing, ballet and modern dance With dance and dance-like expressions Jansson implies exceptional nuances in her narratives and art. With them, she is also able to express her own sense of humour.

* Sirke Happonen, PhD, docent, is an associate professor at the University of Helsinki, Finland. She has published several books and articles on Tove Jansson. 


\section{INTRODUCTION}

Tove Jansson (1914-2001) loved dancing. She knew the dance styles of her time, from waltz to Charleston and jazz. Her friends and relatives remember her improvisatory dances, the quick and often trembling movements that Jansson's life-companion, graphic artist Tuulikki Pietilä, managed to document on cine film, too ${ }^{1}$. In 2000, when I was beginning my research on Jansson's texts and illustrations all this was unknown to me, and not an issue discussed in biographic texts or research on Jansson either. Since I felt intrigued by Jansson's ability to depict movement and stasis with such many nuances both in her art and literature I finally decided to write to her and ask. "Jovisst har dansen betytt mycket - att få dansa." "Dance has definitely meant a lot - to be able to dance." Tove Jansson's answer indicated her wide interest in movement, from ballet to various forms of folk dancing. What she clearly appreciated was spontaneous and improvisatory dance when combined with expressions of emotions ${ }^{2}$.

Jansson's interest in dance can clearly be seen in her work, too. In Moomin books dancing conveys many feelings and phases in the stories: joy of life, rebellion, escapism, liberation and release. The female characters called Fillyjonks dance in order to escape the expectations traditionally addressed to their family; the Moominmamma dances in the sea while washing the rugs. The Moomin parties include happy dancing. Even if a comet is about to destroy the Moominvalley, there is time for a dance, as described in the book Kometjakten (1946, engl. Comet in Moominland). Dancing has a special significance in Jansson's texts for adults, too. In the biographic short story "Quatz' Arts" (1938) Jansson describes the art students of École des beaux-arts of Paris dance on balustrades and restaurant tables and in an exhibition hall among luxury cars and motors as they proceed to Salle Wagram in their annual parade 3 . Sixty years later Jansson portrays a concurrent party of Helsinki art students of Ateneum, the school of visual arts, in a short story called "Avslutningsdag" (1997, The Graduation Day). The first-person narrator, reminding the author herself, twirls Viennese Waltz with her friend "like a crazy", and later, in a park during the early hours, she raises her arms up and lets her feet "dance just the way they wanted"4.

Jansson uses choreographic expressions also when describing and illustrating events that are not actually dance but associate to dance: the movements of the sea or the sand, a growth of the heather on the cliffs of a rocky island, or the little

1 My interviews with Per Olov Jansson on $16^{\text {th }}$ May, 2005 and Tuulikki Pietilä on $29^{\text {th }}$ January, 2008. See also Sophia Jansson, "Nionde augusti - ett sommarminne", in Resa med Tove. En minnesbok om Tove Jansson, H. Svensson (ed.), Helsingfors, Schildts, 2002, p. 212.

2 Tove Janssons letters to me in January and March 2000.

3 "Quatz'Arts" 1938, reprinted in Tove Jansson, Bulevarden och andra texter, S. Happonen (ed.), Helsingfors, Förlaget, 2017.

4 Tove Jansson, "Avslutningsdag", in Meddelande, Stockholm, Bonniers, 1998. 
My's joyful jumping in the middle of a storm. For Jansson, creating illusions of movement works as a vital strategy for both setting and characterisation. Many of her characters seem to move in their specific way, depicted in either text or illustration or both of them.

For Jansson, it was natural to work on the areas of both visual arts and literature, and these two forms affected each other in her work processes throughout her life. Often they were physically combined, not the least on the pages of Moomin her books.

In this article, I will focus on the depiction of dance and dance-like impressions in a corpus of Tove Jansson's illustrations and texts. I attempt to give central examples on the scale Jansson uses dance as an element in her storytelling, for shaping her characters, and for creating setting and thrilling atmospheres. Drawing on the development of social dance tradition and notions of modern dance, especially the ideas of Martha Graham and Rudolf Laban, as well as certain keynotes from picturebook research, I intend to discuss the significance of dance for Jansson's visual and verbal narration. It is also my attempt to reshape and extend these theoretical ideas to cover illustrated novels and short stories, too, not solely picturebooks nor texts that are only children's literature - to books in which writing and illustration seldom create such interwoven combinations and speak to various audiences as they do in Jansson's œuvres.

\section{Movement, Dance and Illustrated Literature}

How dance is displayed in Moomin literature connects with a larger discussion of presenting spatio-temporal movement in illustrated texts. In illustrated literature, of which Jansson's Moomin oeuvre acts as a full-blooded example, the remarks of movement link with the dynamics of the story, alternating situations, depicting action, and the liveliness and diversity of the book as a whole. Illustration may convey movement in various ways. In addition to depicted action and the use of line - which in Jansson's case is mainly drawn with Indian ink - movement serves as a compositional element for instance in visual rhythm ${ }^{6}$. Verbal language in turn produces dynamic expressions through intransitive verbs, emphasizing causality, and by means of rhythmic changes. Because movement as well as dance takes place both in time and space, words and images often share their capabilities and create the illusion together. Since pictures do not literally

5 These remarks have also a background in my published doctoral dissertation which analysed Jansson's books as visual-verbal artefacts, including also their layout, and focused on various areas that images and words express both individually and in co-operation: the illusion of movement and stasis, the illusion of space, and characterisation. Sirke Happonen, Vilijonkka ikkunassa. Tove Janssonin muumiteosten kuva, sana ja liike, Helsinki, WSOY, 2007.

6 On visual rhythm and the line see e.g. Gyorgy Kepes, Language of Vision, 11. printing, Chicago, Theobald, 1964 [1944], p. 174. 
present movement but rather still images of motion, the impression of movement is commonly created together with the flow of the words that the verbal story conveys ${ }^{7}$.

In an illustrated story, the images and words create a continuum, and single images relate to the preceding and the following images as well as to the accompanying text. Respectively, the reading of the text is affected and directed by the images set in connection with it. The illusion of movement takes place in this multimodal continuity, a structure which in best cases accomplishes more than being a sum of visual and verbal meanings. Roland Barthes's point on comics which he calls relaying (relais) relates not only to Jansson's comics and picturebooks but her illustrated novels and short stories as well. In Jansson's work words and images are often "in a complementary relation", they are "fragments of a more general syntagm", and the "message's unity occurs on a higher level: that of the story, the anecdote, the diegesis", as Barthes's argument goes ${ }^{8}$. Movement and dance are pertinent examples of this synergy, I think. Together words and images create impressions of bodily positions that change, mimetic action, alternating scenes and visual angles.

Moreover, the kinetic sensation is founded in personal experience, which enables a resonance when looking at a picture or reading a text - or, when drawing, painting or writing. With this capacity the author or the illustrator as well as the reader is able to understand the aesthetic, psychological and cultural dimensions associated with the depiction of movement. When resonating to sensations associated with dance, this capacity orientates to the aesthetics of dance movement and presumes responsiveness to see choreographic structures also in literary and visual forms of expression.

In the following discussion, I build on Gustaf Cavallius's old idea of movement within a figure from the late 1970's'. Cavallius, who was a Swedish art historian, charted five factors which create motion in illustrations, and this is the one I find useful for the dance context. Movement within a figure arises from the visual form of the figure which can be either fixed or open, with or without a specific

7 On movement in picturebooks see more closely Sirke Happonen, "On Representation, Modality and Movement in Picture Books for Children”, in Visual History, U. Mietzner, K. Myers and N. Peim (eds.), Oxford, Peter Lang, 2005, p. 55-83 (p. 75-81).

8 Roland Barthes, Responsibility of Forms. Critical Essays on Music, Art, and Representation, transl. by R. Howard, Berkeley, University of California Press, 1991, p. 28-29. [Orig. L'obvie et l'obtus, Paris, Seuil, 1982]. Barthes's idea on anchoring (ancrage) also applies to Jansson's illustrated novels and has been applied to picturebook research as well. In the analysis of movement relaying seems especially significant. Picturebook research is semiotically grounded and developed by many researchers. In the context of this article, I am particularly indebted to the thinking of Perry Nodelman, Ulla Rhedin, John Stephens and Maria Nikolajeva.

9 Gustaf Cavallius, "Bilderbok och bildanalys", in Bilden i barnboken, L. Fridell (ed.), Göteborg, Stegelands, 1977, p. 31-60. 
direction, and possibly emphasized by other lines and figures depicted in the picture $^{10}$. To a certain extent, these impressions can be suggested by the text too, I think. There does not need to be depicted movement, argues Cavallius further, pointing at figures that seem to expend energy in opposition to others that seem static and slow. Cavallius's term can well be understood in the context of characterisation. With a focus on choreographic impressions by Jansson in particular, I would consider "the figure" as a body of a fictive character but voluntarily a landscape, too, or a shape of a nature element such as a tree or a rock, even a piece of furniture ${ }^{11}$. A figure that suggests movement is generally depicted in a specific position and shape that implies a direction in the fictive space, pictorial and/ or verbal. It may express physical, mimetic movement but often also mood and intention. It is also worth mentioning that when something is dance or dancelike, it is often aesthetic in a performative sense, too, as some of my next examples of Jansson's books intend to show.

\section{High Knees and a Variety of Styles on a Dance Floor in a Forest}

The first and most salient dance depictions by Tove Jansson are her cheerful party descriptions that portray forms of conventional dancing with a more or less social function. The first big dancing scene in Moomin literature takes place in her second Moomin book Comet in Moominland (orig. Kometjakten, 1946) ${ }^{12}$. In this story, Moomintroll, Sniff, Snufkin, Snorkmaiden and Snork have found out that a comet is approaching Moominvalley and they hurry home in order to warn the family about the becoming disaster. However, on their way they become attracted by a sign and decide to pay a visit in an open-air dance floor in the forest. This dance is couple dancing accompanied by a grasshopper:

There was a dreadful muddle at first when they all tried to sort each other out, but at last everybody found the person he wanted to dance with, and they started off.

The Snorkmaiden taught Moomintroll how to dance the samba (which isn't at all easy if you have very short legs). The Snork danced with an elderly and respectable inhabitant of the marshes, who had seaweed in her hair, and Sniff twirled round with the smallest of the small creatures. Even the midges danced, and every possible kind of creeping thing came out of the forest to have a look. And nobody gave a thought to the comet that was rushing towards them, lighting up the black night with its fierce glow. ${ }^{13}$

10 Ibid., p. 40-42.

11 On Jansson's chairs and the connection between gaze and movement, see Sirke Happonen, "The Fillyjonk at the Window: Aesthetics of Movement and Gaze in Tove Jansson's Illustrations and Texts", in Tove Jansson Rediscovered, K. McLoughlin and M. Lidström Brock (eds.), Newcastle (UK), Cambridge Scholars Publishing, 2007, p. 54-74 (p. 66-67).

12 Kometjakten, Helsingfors, Söderström \& Co, 1946. In English, Comet in Moominland, transl. by E. Portch, London, Ernest Benn. 1951.

13 Ibid., p. 128. 
Tove Jansson has illustrated this scene, as most of her dance descriptions in Moomin books. As the text clarifies who is dancing with whom, the illustration covers a variety of dance styles, or, to be exact, illusions of them (Image 1). In the middle, Sniff and his tall partner seem to glide with long and low steps, while as the two insects as well as Moomintroll and Snorkmaiden demonstrate the most traditional type of dancing in Jansson's images: cheerful-looking motions that include hopping leg-positions and quick steps. This dance makes its appearance already in Jansson's childhood drawings and her illustrations for the magazine Garm, a Finland-Swedish cultural paper with political satire which Jansson started illustrating at the age of $15^{14}$. In these dance depictions Jansson draws her characters with outstretched ankles, open leg positions and bended knees. The knees raise high and the feet look both thin and flexible compared with the rest of the body. With the round-shaped Moomins, this creates a particularly comic effect.

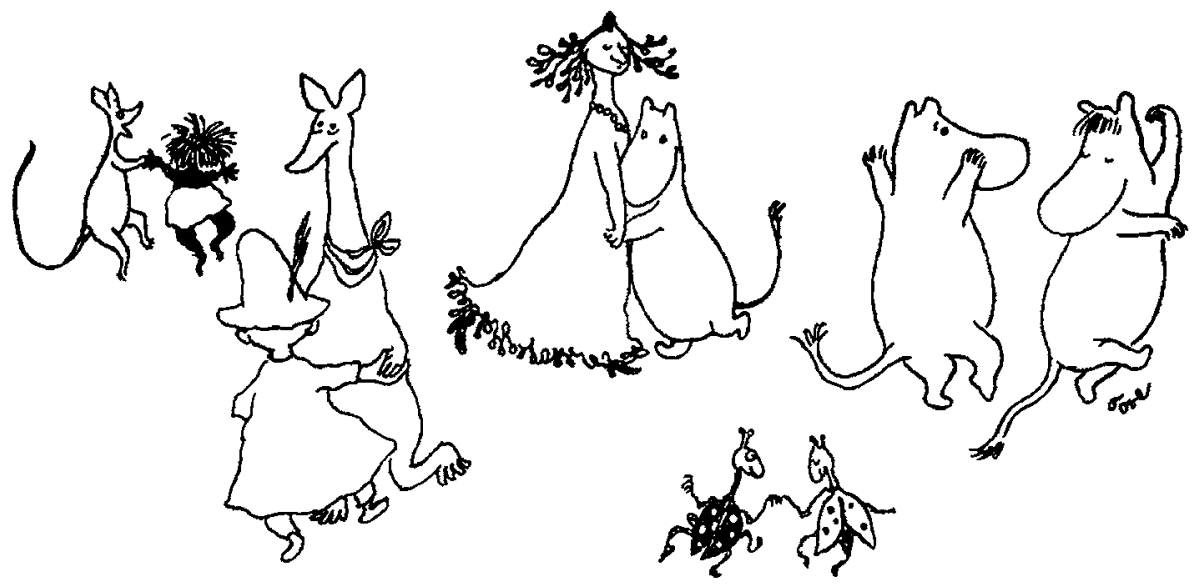

Image 1

MoominCharacters $\bigodot$

The only dance named in the text is samba. It however exists solely in the English translation from 1951 - in the original Kometjakten of 1946 Snorkmaiden teaches Moomintroll swing. During the 1950's and the late 1960's Tove Jansson made several changes to a corpus of her Moomin books and to some of their translated editions, too. Kometjakten was the book she revised most. The changes were that significant that the newer editions of the Swedish-language comet book were published with separate titles: ten years after Kometjakten came out Mumintrollet på kometjakt (1956) and in 1968, Kometen kommer. It was Jansson's idea to revise her books, mostly text but also illustrations here and there: she wanted to cut out unnecessary details of the story and make her landscape more Nordic to

14 See Tove Jansson's cover illustration for Garm, May 1943, Helsingfors; and Sirke Happonen, Vilijonkka ikkunassa, op. cit., p. 138-141. 
be in line with her later Moomin books starting from Moominland Midwinter on (orig. Trollvinter, 1957)..$^{15}$

It is remarkable, that all the three editions of the comet book also name different dances. In the book's second Swedish edition Mumintrollet pa kometjakt, the dance is mambo, while as the last version, Kometen kommer relies on improvisation and avoids naming any particular dance qualities. The sentence that in the earlier versions (as well as in the English translation) describes the style Snorkmaiden and Moomintroll dance in the beginning of the dance-floor scene, is in Kometen kommer replaced by the following dialogue:

"You dance very well," Snorkmaiden said. "What is it for a dance?"

"My own," said Moomintroll. "I just made it up!"16

Jansson's switches from swing to samba, mambo and finally to undefined improvisatory dances reveal the author's interest in the popular dance styles in different periods of time. These may look like delightful curiosities but they also tell about an understanding of what humoristic nuances such playful details may bring to fictive narratives, especially to characterisation. The discussions on dance (also before the quoted dancing scene) uncover that Moomintroll is not as aware of the conventions and styles of social dancing as Snorkmaiden implies to be. Yet he like Snufkin clearly wants to dance - it is only the Snorkmaiden's serious and rational brother, the Snork, who is against dancing and wants the others to concentrate on the threat of the comet.

Jansson's two comic-strip versions of the same story also diverge in their dance style depictions of this scene. In the early Mumintrollet och jordens undergang from 1947-1948 Moomintroll asks Snorkmaiden for "a minuet because he did not know the steps for rumba (which was why he deeply disliked this barbarian dance)" ${ }^{\prime 7}$. The Moomins are not directly up to date with the newest dance movements in the comic Moomin and the Comet (1958) either, published for the first time in The London Evening News. In this comic story, which Tove Jansson and her brother Lars Jansson did together, Moomintroll and Snorkmaiden try to dance to cool jazz and possibly also to rock. This time they do not dance with each other but with accidental partners they meet in a party. Their arrogant dance

15 Mumintrollet på kometjakt, Norrköping, Sörlin, 1956; Kometen kommer, Helsingfors, Schildts, 1968. On Jansson's revisions see Boel Westin, Familjen i dalen, Stockholm, Alfabeta, 1988, p. 11-14, p. 288; and Agneta Rehal-Johansson, Den lömska barnboksförfattaren. Tove Jansson och muminverkets metamorfoser, Göteborg, Makadam, 2006, e.g. p. 88-98, 170-175; and Sirke Happonen, Vilijonkka ikkunassa, op. cit., p. 290-295.

16 Kometen kommer, op. cit., p. 94. (Translation of the paragraph S.H.)

17 My translation of the quoted paragraph. Jansson's Mumintrollet och jordens undergang (Moomin and the End of the World) was published as a serial comic-strip story in the politically left-wing magazine Ny Tid during 1947 and 1948. It has been republished under the name Jorden går under! Tove Jansson's forsta muminserie i Ny Tid 1947-1948, Helsinki, Tigertext - Ny Tid, 2007. 
partners make clear that they fail: both Moomintroll and Snorkmaiden are left standing on the floor in the middle of a dance piece.

In her variants of the comet story between 1946 and 1958 Tove Jansson displays a considerable range of dance styles. Yet one element remains the same. In a discussion before the actual dance-floor scene Moomintroll reveals Snorkmaiden his very favourite dance. This is, from version to version, always waltz. No doubt, waltz supports Jansson's characterisation of Moomintroll: he is a kind, sensitive and romantically oriented figure in the Moomin series, a hero whose romanticism is often seen in a parodic light, too.

\section{Mymble's Dance and the Threat Outside}

In Jansson's stories, the illustrations and the text often highlight the dancing scenes from alternative angles. As Mymble dances in Moominvalley in November (orig. Sent i november, 1970), the illustration emphasizes the coquetry and reserve that define the first part of the her performance. According to the text, Mymble looks "very shy and self-conscious" and circles "with short, hesitant steps"18. Jansson's drawing portrays Mymble in a conventional posture, framed with two clichéd bows (Image 2). The bow decoration builds a stage for the depicted scene and underlines the artificiality of her posture, and at same time, the whole situation the dance takes place in the story.

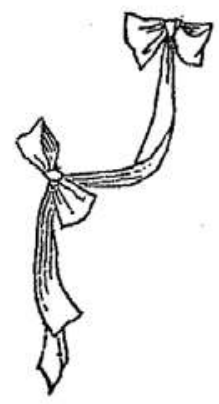

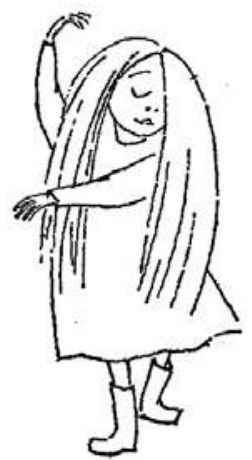

Image 2

MoominCharacters@

Moominvalley in November, the very last Moomin novel, stages the last party in the Moomin-book œuvre, an evening at the kitchen of the Moomin house with Fillyjonk, Snufkin, Hemulen, Grandpa-Grumble, Whomper and Mymble. The Moomins themselves are absent from the party as well as the whole book. This

18 Translation Kingsley Hart, Moominvalley in November, London, Ernest Benn, 1971. Originally Sent $i$ november, Helsingfors, Schildts, 1970. 
get-together aims at the liveliness typical for Moomin parties but turns out to be a rather constrained and awkward gathering ${ }^{19}$. In the text, however, Mymble's dance grows to a happy, verbal crescendo. It gets wild and merges into a unison movement performed together by the dancer, the musician, the audience, and even the elements of the setting, the paper decoration:

The guests beat time with their feet and sang tiddledidi, tiddledidoo, Mymble kicked off her boots, threw her scarf to the floor, the paper streamers fluttered in the warmth from the stove, everybody clapped their paws and Snufkin stopped playing with a loud cry! Mymble laughed with self-satisfied pride. ${ }^{20}$

As Mymble dances, the otherwise stagnant atmosphere of not just the party but most of the whole story of Moominvalley in November becomes filled with momentum and energy. The verbs indicating movement set pace for the long sentence (Jansson's structure that the translator has maintained), and the commas accentuate the glimpses of motion in various parts of the room that together construct a continuum. The standstill ("and Snufkin stopped playing...") is finalised with an exclamation mark which also points a climax and as it were, a jump upwards. And as a descending hand movement the narrator describes Mymble's reaction in the end of the performance: "And Mymble laughed with self-satisfied pride."21

As depictions of pure joy and a growing feeling of togetherness Comet in Moominland and Moominvalley in November - the first and the last dance depictions of the Moomin novels - have a lot in common. Another interesting point of resemblance in both of the two books is the narrator's sudden move away from the dance scene, a separate sentence in which the narrator describes a possible danger not far from the dancing event. In Comet in Moominland, the narrator informs that the dancers have forgotten the approaching comet (see the quoted paragraph in the previous chapter of this article). In Moominvalley in November, in the middle of the description of Mymbles's accelerating dance, the narrator says: "No one heard the Creature, huge and heavy, creeping round and round the house without knowing what it wanted." 22 According to the narrator, the participants are unaware of the close presence of a Creature, a Nummulite, who is an archaic and ambiguous being, described in the story mostly from Whomper's point of view, a perspective which occasionally fuses with the narrator's focalisation.

19 See my analysis of the Moomin parties in "Parties as Heterotopias in Tove Jansson's Moomin Illustrations and Texts", The Lion and the Unicorn, 38 (2), 2014, p. 182-199.

20 Moominvalley in November, op. cit., p. 140. Translation Kingsley Hart.

21 "Och Mymlan skrattade av stolthet", says the Swedish original. The presence of $o c h$ (and) increases the impression of the descending movement in the end of the original paragraph, I think.

22 In Jansson's book, this sentence is right before the paragraph cited above. Moominvalley in November, op. cit., p. 139-140. 
The contrast between the vibrant dancing scenes and the simultaneous, possible threat outside can be seen in a bigger picture with Jansson's common tendency to contrast the ideas of idyll and destruction in her art and writing, a juxtaposition brought up by Jansson herself and later, by several researchers. ${ }^{23}$ In the Kometjakten dance floor this contrast has, however, a further historical connection to the context the book was written, the end of the Second World War. The comet described in the book has been interpreted for instance with a reference to the fear of a nuclear war that time, and in connection with the atomic bombs dropped in Japan in August $1945^{24}$.

Moreover, what is at least as interesting is how the dance floor of the forest also refers to the forbidden nature of dance and celebration during the era of war. In this context the first Moomin ball is of rebellious nature. It illuminates ways to cope with depressive times which convey a constant consciousness of threat, loss and sacrifices. During the war, parties and celebrations felt more necessary than ever and were often intense and frantic of nature. In her letters and postcards of the wartime Jansson mentions parties every now and then. She describes them with miscellaneous words: sometimes they are strange, sometimes rough and two-day-long, sometimes fun, then miserable, passionate or lively. At the time parties were formally disapproved. Dancing was officially forbidden in Finland for most of the Second World War. Dance floors were closed and surrounded with barbered wire, some even burned down, and the police guarded their illegitimate use. Only a newlywed couple was allowed for a waltz. People however organised secret dance events, and taking a dance course was not a crime ${ }^{25}$.

Tove Jansson has also portrayed a war time party, in an oil painting called Nachspiel (Dagen efter) in 1941. Compared with the Moomins' exuberant dance in the forest of Comet in Moominland the atmosphere of the painting, sited in an apartment that looks like a Helsinki atelier, seems desolate. The setting is ascetic, and tones of cold and pale green dominate. Bottles fill a small table and lonely men look in different directions. Only a newlywed couple is dancing, another couple sits by the table kissing each other, possibly drunk. The interior is a chaos

23 Tove Jansson has brought up this issue in several of her speeches and a couple of essays, in e.g. "Den lömska barnboksförfattaren" (1961), republished in Bulevarden och andra texter, op. cit.

24 According to Boel Westin the script of the book Kometjakten was in August 1945 rather ready and not necessarily influenced by the atomic bombs. See Boel Westin, Tove Jansson. Ord, bild, liv, Stockholm, Bonniers, 2007, p. 107. (On Jansson's apocalyptic motifs in Comet in Moominland see Happonen, "Hilpeä apokalypsi: luonnonkatastrofi Tove Janssonin romaanissa Muumipeikko ja pyrstötähti”, in Tapion tarhoista turkistarhoille. Luonto suomalaisessa lasten- ja nuortenkirjallisuudessa, M. Laakso, T. Lahtinen and P. Heikkilä-Halttunen [eds.], Helsinki, SKS, 2011, p. 151-161.)

25 See e.g. Maarit Niiniluoto, "Tanssilavat ovat olleet 1920-luvulta lähtien suomalaista kansallisromantiikkaa", POMUS - Populaarimusiikin museo, [http://pomus.net/kehityslinjat/tanssilavakulttuuri] (last visited in February 15th 2018). 
with chairs here and there and a flower bunch and a violin lying on the floor ${ }^{26}$. In a postcard to her friend Eva Konikoff Jansson described her painting as ruthless and frank, pondering on whether she will soon "be told-off" by the critics ${ }^{27}$.

In both Comet in Moominland and Moominvalley in November dance marks an uplifting moment of togetherness in the narrative. Jansson interrupts the flow of events with a dance scene that in a way stops time. For the course of the story, the moment of dance seems like a separate excursion, a break in a longer section which otherwise tells about a return to home in a landscape that is becoming more and more miserable (Comet in Moominland), or a party night which lacks a collective feeling and consists of programme in which the participants mainly speak past one another (Moominvalley in November). The comet and the desolate Nummulite, both described as immense, incalculable and aggressive, electrify the description of the dance scene and make it even more significant. Mentioning the presence of them creates excitement for the scene but it also shows how total the moment of dancing or watching a dance may be. "Nobody gives a thought" to a possible destruction nor a nameless threat, explains the narrator. Destruction, loneliness, aggression and whatever the comet and the Creature may imply is wiped out of the consciousness of the characters in the stories - because there is dance that takes place.

\section{Primitive, Down-to-Earth Movement and Modern Dance}

In Jansson's books many characters have individual movement languages. Quick tempos and large movement sequences are more typical to some than others, and little My is so light that her feet make "no tracks at all in the snow" ${ }^{28}$. The Moomins may like waltz but they also represent comical ballet dancers. Although heavy and round, their body shape gives an impression that the focus of their gravity is situated high, resembling the ethereal emphasis of classical ballet. In addition, Tove Jansson draws their feet and hands rather small and slender compared to the rest of their bodies. Simultaneously heavy and light the Moomins seem to move delicately, which creates a unique effect and fits with their "seriously comical" nature ${ }^{29}$. The long-limbed Fillyjonks and Gaffsies in turn seem closer to representatives of modern dance. They call to mind the principles of

26 Tove Jansson, Nachspiel (Dagen efter), oil on canvas, 1941.

27 Tove Jansson's postcard to Eva Konikoff in to the United States in 27th January, 1942. Printed in Brev från Tove Jansson, B. Westin and H. Svensson (eds.), Helsingfors, Schildts \& Söderströms, 2014.

28 Moominland Midwinter, op. cit., p. 33. Translated by Thomas Warburton, London, Ernest Benn, 1958. Originally Trollvinter, Helsingfors, Schildts, 1957.

29 This effect has been experimented on stage as well. I have had the joy to be involved with two dance performances based on Jansson's Moomin books: the ballet Moomin and the Comet by Finnish National Ballet, Helsinki, with the choreography by Anandah Kononen, 2015; and contemporary dance performance Dancing Moominvalley (based on Tales of Moominvalley) by Dance Theatre MD, choreography Samuli Roininen, Tampere, 2010. 
modern dance introduced by the dancer and choreographer Martha Graham (1894-1991). According to Graham the movement emerges in the spinal cord of a character and proceeds then to the periphery of the body such as hands and feet ${ }^{30}$.

Beginning from the late 1950's, Jansson's movement language generally changes. It becomes more expressive and powerful in both illustration and text ${ }^{31}$. Conventional dancing carried out by couples and dance forms such as swing, mambo and waltz disappear. Dancing and moving becomes more down-to-earth, even primitive. The shadows dance their wild dance around a fire lit up on an icy cliff in one of Jansson's full-page illustrations for Moominland Midwinter (originally Trollvinter 1957) ${ }^{32}$, and for an illustration drawn for J.R.R. Tolkien's Hobbit in 1962, Jansson builds a vertical composition with even higher flames and an impression of almost transcendental movement. In her image (Image 3), wolves and bloodthirsty goblins go wild in the flames that blaze through the picture from below upwards $s^{33}$.

Jansson also uses more and more choreographic expressions describing and illustrating events that are not actually dance but associate to dance. The collection of short stories Tales of Moominvalley (orig. Det osynliga barnet, 1962) implies a lot of dance-like dynamics which in my opinion relates especially to the movement language of modern dance. In her letter to me, Jansson told that with this particular book she had had a special technique when doing the illustrations. She drew quickly 10-50 illustrations of a single motif and then chose one drawing to fit with the story ${ }^{34}$. When studying her sketches - or, the illustrations she did not choose for the final book - my overall impression was that they include a lot of movement, often stronger and more expressive than the ones Jansson chose to accompany her text ${ }^{35}$.

30 Martha Graham, "Modernin tanssijan toiminnan aakkoset", in Hetken vangit - koreografien ja tanssikriitikkojen kirjoituksia, T. Suhonen (ed.), Helsinki, VAPK-kustannus. Teatterikorkeakoulun julkaisusarja nro 12, 1991, p. 105. [Originally "A Modern Dancer's Primer for Action”, in Dance. A Basic Educational Technique, F. R. Rogers (ed.), New York, Dance Horizons, 1941.]

31 The change in choreographic expressions in Moomin books parallels the general development of Jansson's œuvre. Despite of the threatening motifs such as floods and comets the early Moomin books published in the 1940's and early 1950's are commonly cheerful and adventurous. The later Moomin books, especially the ones published in the 1960's and 1970's, focus more on the interiority of the characters.

32 Moominland Midwinter, transl. by T. Warburton, London, Ernest Benn, 1958, p. 61. Originally Trollvinter, Helsingfors, Schildts, 1957.

33 J. R. R. Tolkien, Bilbo. En hobbits äventyr, transl. into Swedish by B. G. Hallqvist, Stockholm, Rabén \& Sjögren, 1962. [Originally The Hobbit or There and Back Again, 1937.]

34 Jansson's letter to me in January $1^{\text {st }}, 2000$.

35 See Sirke Happonen, Vilijonkka ikkunassa, op. cit., e.g. p. 143, p. 153-154 and p. 170. 


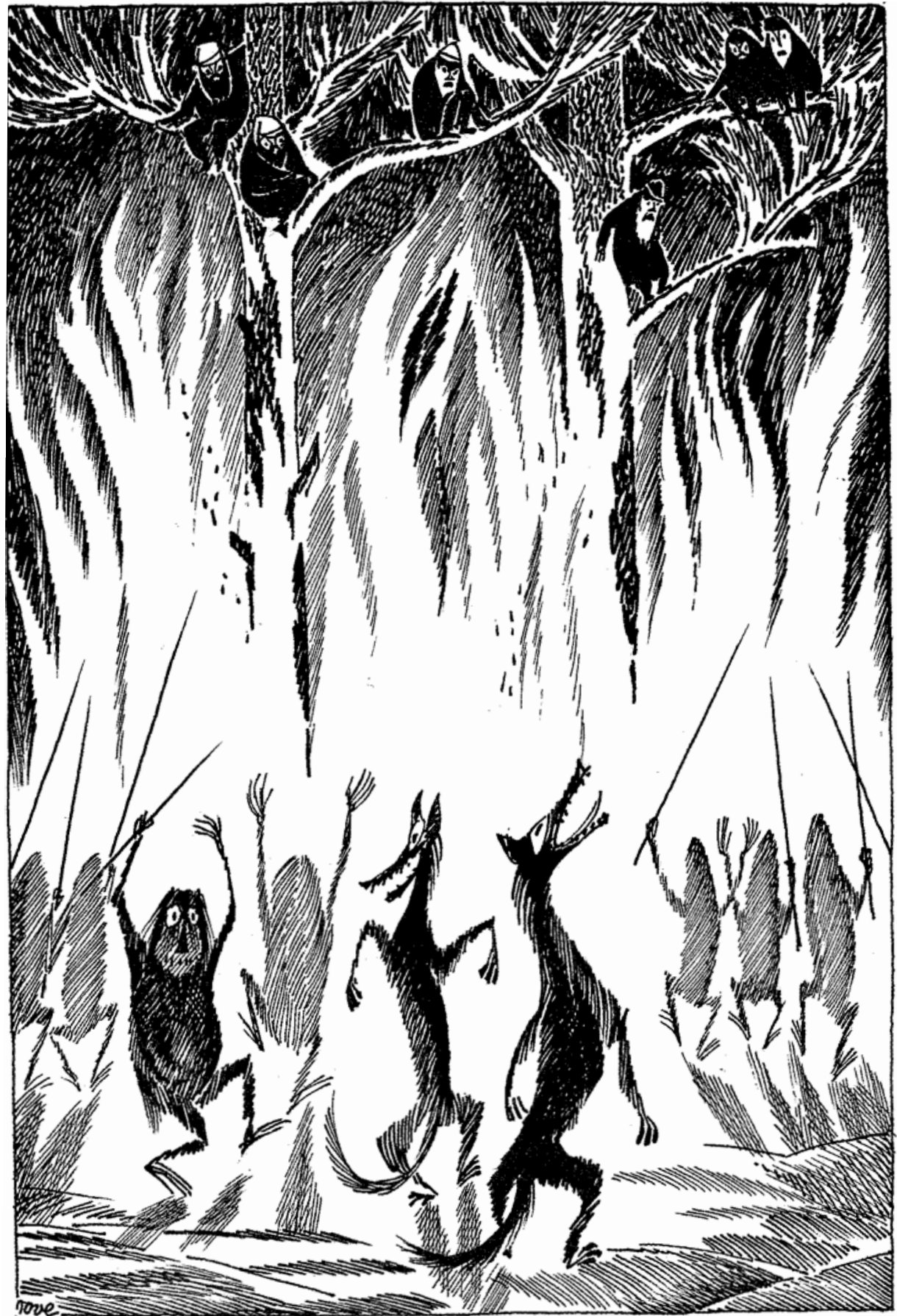

Image 3

MoominCharacters@ 
Graham's concepts of contraction and release offer interesting opportunities for the analysis of certain characters and settings in Jansson's books. Contraction is a movement which makes the lower or the upper back (or both) go round and curve inwards, to "contract". Release is its counter-motion. In an illustration, contraction may look like a drooping position or a shortening of a posture of a fictive character, while as a dancer's movement is usually active. Contraction can express sorrow, fear or shrinking inwardly; release may give an impression of acceptance, assurance or ecstasy. Regarding illustrations and literature, contraction and release overlap with Cavallius's ideas of closed and open shapes suggesting movement within a figure ${ }^{36}$. It is worth mentioning that contraction is not necessarily negative and release positive, but when followed by each other and possibly accompanied by facial expressions, the two positions can construct mood and narrative meaning.

Postures and positions are especially significant for Jansson's characterisation in Moomin books after Moominland Midwinter. In her texts, Jansson uses several contraction-like expressions that imply movement and mood: the lonely Moomintroll curls up close to her mother and the Hemulen shrinks inwardly when the others laugh at his dream of building an empty doll's house ${ }^{37}$. In Moomin books, one of the most dynamic figures is the Fillyjonk who is often depicted in opposition to the other less mobile and plumper characters. In Jansson's book cover illustrations for Moominvalley in November, for instance, the Fillyjonk's contour line establishes directions that cross the major lines of the pictorial composition ${ }^{38}$. In some images she is depicted running wildly, her long dress flapping about, but Jansson draws her also in complete stasis in the same book, standing still in a doorway and staring at the dusk.

The short story "The Fillyjonk who Believed in Catastrophes" 39 in Tales from Moominvalley tells about a Fillyjonk who lives alone by the sea shore and is afraid of storms. At the same time she anticipates a great gale, a catastrophe which would be "one of her own". As the storm finally comes, the text is full of descriptions about the Fillyjonk crawling as well as curling up, in blankets and closets in her house. In terms of modern dance, her movements represent various forms of contraction. But in Jansson's full-page illustration depicting the same scene we see what could be a release of this position (Image 4).

The drawing illustrates the moment when the storm breaks into the Fillyjonk's house and smashes one of her tall windows. In the image, the Fillyjonk's position

36 Gustaf Cavallius, "Bilderbok och bildanalys", op. cit.

37 In Swedish: krypa ihop, krympa invärtes.

38 See Jansson's first cover illustrations for Schildts, Bonniers, WSOY and Ernest Benn.

39 "Filijonkan som trodde på katastrofer", in Det osynliga barnet, Helsingfors, Schildts, 1962. In English Tales from Moominvalley, transl. by T. Warburton, London, Ernest Benn, 1963. 


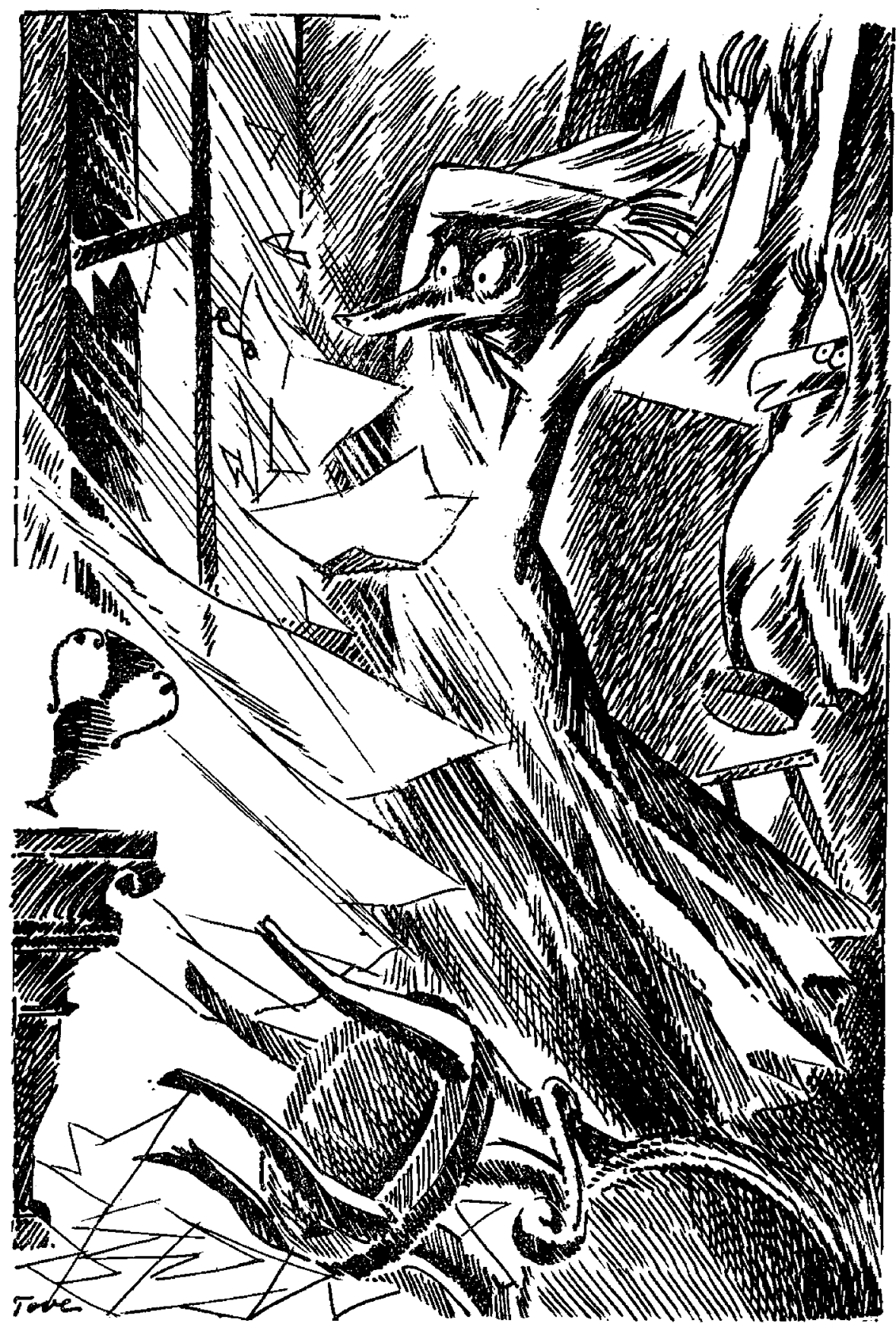

Image 4

MoominCharacters@ 
is pronouncedly aesthetic and open. Her hands, her body, her dress all take part in the movement of the wind. She leans towards the storm while broken pieces of glass rain in from the window in a diagonal flow. Not covering her eyes nor her chest, she seems both shocked and energized. In the text, the narrator describes this moment with strong, dramatic verbs and, in turn, an inward movement in the Fillyjonk's posture:

She got hold of a china kitten and pressed it hard in her paw [orig. emot sig, against herself]. Then a window flew open and shattered its pane in small fragments over the floor. A gust of rain spattered the mahogany furniture, and the stately [orig. vackra, beautiful] plaster hemulen threw himself from his pedestal and broke into pieces. ${ }^{40}$

In the pictorial composition, the statue of the hemulen (depicted on the right side of the Fillyjonk), represents the euphoric side of the Fillyjonk's storm. The original Swedish text tells about "a beautiful plaster decoration falling and breaking into pieces" ${ }^{\prime \prime}$. In the illustration, however, the movement of the statue is directed upwards, happily. As an echo of both the Fillyjonk's posture and her facial expression, the hemulen statue functions as a shadow movement in relation to the protagonist's intentions in the story. According to Rudolf Laban (1879-1958), a dance artist and theorist, shadow movements either precede or accompany the primary efforts in a dynamic content. Shadow movements give further information on the feelings, intentions and purposes a dancer is expressing. Compared to more obvious intentions shadow movements may appear as contrasting or parallel movements, Laban argues ${ }^{42}$.

In the Fillyjonk's breaking window scene the ambivalence around the figure of the Fillyjonk manifests itself in the relationship between illustration and text. As the text depicts her in fearful, contract-like postures and emphasises the loss of her beautiful decoration and furniture, all the destruction the Fillyjonk sees in her house, the illustration shows her ecstasy, her anticipation of the catastrophe that fills her with sudden energy. The Hemulen statue's jump precedes the growing feeling of rebellion and freedom in the Fillyjonk. Soon the text describes how the Fillyjonk herself jumps, too, out of her window into the gale. Her liberation reaches its final culmination in the end of the story, as she walks majestically towards a tornado with upheld arms, and laughs and dances in the sea waves while washing her rug.

40 "The Fillyjonk who Believed in Catastrophes", in Tales from Moominvalley, op. cit., p. 53, 55. Translation Thomas Warburton. [In brackets, S.H.]

41 Originally: "den vackra gipshemulen störtade sig ner frän sin piedestal och splittrades". Det osynliga barnet, op. cit., p. 126.

42 Rudolf Laban, Modern Educational Dance, 2. ed., London, Mcdonald and Evans, 1971 [1963], p. 46. 


\section{LANDSCAPE MOVES}

In Moominpappa at Sea (Pappan och havet, 1965) ${ }^{43}$, Jansson lets a whole landscape move. The ambiguous verb "krypa", to crawl, to creep, is a word that Jansson varies and uses profoundly in her texts. In Moominpappa at Sea this verb - together with its derivatives and synonyms - seems to build up an intriguing tension between the characters and their environment:

The heather disappeared in a mossy swamp in the middle of the island, came out the other side, only to vanish in a low thicket of spruce and dwarf birch. It was odd that there wasn't a single tall tree. Everything seemed to grow so close to the ground, groping its way across the rock. It occurred to Moomintroll that he, too, should make himself as small as he could. He began to run towards the point. ${ }^{44}$

In translation some of this low-going movement is diminished, so here the original:

Ljungmarken sjönk mot en liten grön mosse mitt på ön, så klättrade den uppåt igen och försvann $i$ ett låg snår av gran och dvärgbjörkar. Så underligt att inte bo tillsammans med ett enda stort träd. Allt som växte var lågt, kröp tätt intill marken, trevade sig fram över berget-mumintrollet fick för sig att han ocksa borde gå på alla fyra och göra sig liten. Han började springa mot udden. ${ }^{45}$

A low, crawling movement characterizes both Moomintroll and the heather growing on the island, a barren place that the Moomin family inhabits in the book. In his thoughts, the Moomintroll is said to take a similar position with the landscape in the island, he feels like moving as the heather and the spruce do. Finally, he chooses to fight the suggestion of the ongoing low-level movement by running away as the quoted chapter reveals. In her illustrations for the book, Jansson in turn depicts the tension between the nature and the characters by building a contrast. Often, she depicts a static character in a dynamically drawn landscape, invoking a captivating atmosphere but also a tone of humour (Image 5). Moomintroll sits almost petrified among the low and wild vegetation, depicted with lines that point arbitrarily in various directions. In many images of Moominpappa at Sea, Jansson generates stasis by depicting stagnant postures but also drawing the Moomins' eyes in a specific way: she illustrates them big and with large pupils, implying sometimes a gaze into the far distance, or, as in the enclosed image, rather a gaze inwards, towards the character himself.

43 Pappan och havet, 1965, Helsingfors, Schildts, 1965. In English, Moominpappa at Sea, transl. by K. Hart, London, Ernest Benn, 1966.

44 Moominpappa at Sea, op. cit., 1965. Translated by Kingsley Hart, p. 41-42.

45 Pappan och havet, op. cit., p. 36-37. 


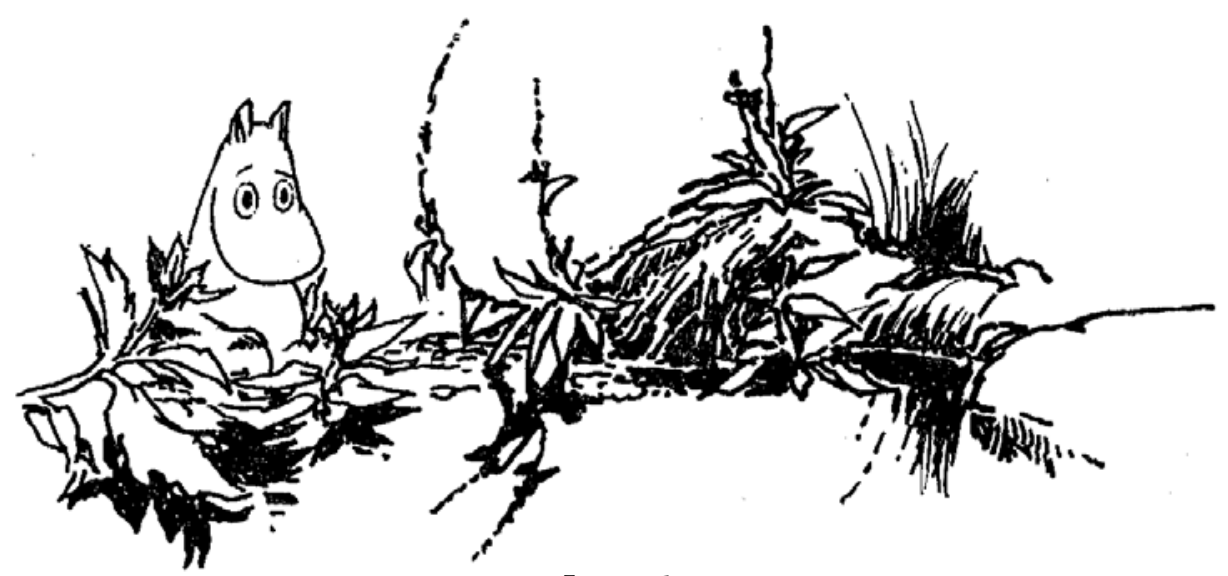

Image 5

MoominCharacters@

A landscape that crawls is able to generate a feeling of excitement, even horror. As Groke, the lonely and mysterious monster of the Moomin oeuvre, follows the Moomin family and enters the small island in Moominpappa at Sea, the sand starts to escape, crawling in the direction of the sea. The trees move closer to the lighthouse, calling to mind Birnam forest in Shakespeare's Macbeth - yet, in Jansson's story, the trees are seeking shelter. Finally, Jansson anthropomorphises the whole island in her description of the Groke's repeated visits. The huge blocks start to tremble and vibrate, the swamp sinks inside of the earth. The entire landscape becomes full of breathing movement, contractions and releases, both towards the centre of the island as well as outwards, to the direction of the sky and the sea.

But it is not only Groke's presence that invokes the dramatic movement in the island. She dances. A night after another, watching Moomintroll's oil lamp and making the landscape totally and literally out of place.

How can a big rock, whose shape is nearly inseparable from the icy ground she stands on, dance? As Jansson warms up her coldest and loneliest character by letting her slowly make contact with someone, the Moomintroll, Jansson changes her movement language too. Jansson describes how the Groke, before this primarily depicted as gliding from place to place, now starts slowly swaying, waving up and down her skirts that remind bats' wings, dancing her heavy dance with the accompaniment of her own whining song and the sound of her steps. But Jansson does not illustrated the Groke's dance at all. Why? Leaving the scene unillustrated relates to one of Jansson's principles, I believe, which she has expressed in a few of her essays and speeches when discussing her work as a children's-book author. 
The most dangerous, the most beautiful should not be illustrated, hardly even described, was one of Jansson's premises as an illustrator and author ${ }^{46}$. The Groke's dance is something that earth-shattering, that the reader should picture it herself.

\section{Conclusion}

This article has aimed at highlighting Tove Jansson's work from a point of view that was important and dear to herself, an art form that was for her rather a hobby than a profession. For Jansson, dance represented a means for experiencing and thinking, an instrument and a framework she used for constructing narratives and pictorial spaces, compositions and characterisation. Thinking dance-wise she was able to imply exceptional nuances and moods in her work from serious to cheerful and from comic to tragicomic, and depict both joyful togetherness and the horror of the lonely moments as well as imply energy and dynamic changes in her illustrated texts. Also, she was able to create such ambiguous and interesting characters as the Fillyjonk. To me, Jansson's ability to resonate to movement and express its aesthetical dimensions gives one central explanation for her originality and brilliance as an artist.

With this article I have tried to illuminate the varied scale Jansson implies and expresses movement and dance in her texts and illustrations, especially Moomin books. Several interesting examples and notions have fallen out the scope of this article or have just been touched briefly. One intriguing notion is Jansson's ability to create also stasis which builds a vital contrast for movement in her images and texts. Without stasis the effect of movement is lower, and without movement, or at least the possibility of it, there is no stasis. In addition, many Jansson's dancing scenes are accompanied by music which is performed by musicians such as the Snufkin (mouth-organ) or the grasshopper (violin), or, a gramophone which is playing in a corner of a room or in an outdoor party. The dancers of the Moominworld are interested in what kind of music they are moving to. Some are quite picky. "That sounds modern", say the small creatures in the forest party in Comet in Moominland. "You can dance to that!"

46 See e.g. Jansson, “Den lömska barnboksförfattaren”, 2017 [1961], p. 200-201, 205-206.

47 Comet in Moominland, op. cit., p. 126. 